\title{
Pemerintah dan Peranannya dalam Pelayanan Pengurusan Kartu Tanda Penduduk (KTP) di Kecamatan Lubuk Baja Kota Batam
}

\author{
Meri Enita Puspita Sari \\ Program Studi Ilmu Pemerintahan Fakultas Ilmu Sosial dan Ilmu Politik \\ Universitas Riau Kepulauan, Batam Indonesia \\ puspita.meri@yahoo.co.id
}

\begin{abstract}
This study is intended to see how the government service in the management of identity card (KTP) either from the apparatus or from its role. Identity Card (KTP) is one of the mandatory identity that must be owned by every citizen of Indonesia and has been regulated by the rules in effect so that in the implementation of society must get good service. A policy will be successfully implemented if the government apparatus in running it in the community in accordance with the role and rules that apply and the community must also accept and support the policy so that there is a good interaction. Lubuk Baja sub-district has performed its role and provide maximum services, but there are still obstacles in terms of human resources, access and facilities. The importance of increasing human resources by providing training and training for the socialization, implemtation and evaluation of the policy can work well, the government should also provide easy access for the community and the addition of facilities that support the role and services to run well.
\end{abstract}

Keywords: government, role, public service

\begin{abstract}
Abstrak
Studi ini bertujuan untuk melihat bagaimana pelayanan pemrintah dalam pengurusan kartu tanda penduduk (KTP) baik itu dari aparaturnya ataupun dari peranannya. Kartu Tanda Penduduk (KTP) merupakan salah satu identitas wajib yang harus dimiliki setiap warga Negara Indonesia dan sudah diatur oleh aturan-aturan yang berlaku sehingga dalam pelaksanaannya masyarakat harus mendapatkan pelayanan yang baik. Suatu kebijakan akan berhasil dilaksanakan apabila aparatur-aparatur pemerintah dalam menjalankannya dimasyarakat sesuai dengan peranan dan aturan yang berlaku dan masyarakat juga harus menerima dan mendukung kebijakan tersebut sehingga terjadi interaksi yang baik. Kecamatan Lubuk Baja sudah menjalankan peranannya dan memberikan pelayanan yang maksimal, hanya saja masih terdapat kendala dari segi sumber daya manusia, akses dan fasilitas-fasilitas. Pentingnya peningkatan sumber daya manusia missal dengan memberikan pelatihan dan diklat agar dalam tahap sosialisasi, implemtasi dan evaluasi kebijakan dapat berjalan dengan baik, pemerintah juga harus memeberikan kemudahan akses bagi masyarakat dan penambahan-penambahan fasilitas yang mendukung peranan dan pelayanan agar berjalan dengan baik.
\end{abstract}

Kata Kunci : pemerintah, peranan, pelayanan publik

\section{PENDAHULUAN}

Kartu Tanda Penduduk (KTP) merupakan identitas resmi seluruh warga Negara Indonesia yang wajib dimiliki apabila sudah berusia lebih dari 17 tahun dan pemerintah merupakan instansi yang berkewajiban dalam memberikan pelayanan tersebut. Berdasarkan Peraturan Daerah Kota Batam No 8 Tahun 2009 Kartu Tanda Penduduk (KTP) adalah identitas resmi penduduk sebagai bukti diri yang diterbitkan oleh instansi pelaksana yang 
berlaku di seluruh Wilayah Negara Kesatuan Republik Indonesia. Akan tetapi fakta empiris di masyarakat masih banyak penduduk yang belum memiliki Kartu Tanda Penduduk (KTP), kemungkinan besar disebabkan oleh lambatnya aparatur serta berbelit-belitnya proses yang dilalui dalam pengurusan Kartu Tanda Penduduk (KTP) tersebut, serta kurangnya informasi yang diberikan kepada masyarakat mengenai besarnya biaya dalam pengurusan KTP, atau tidak adanya kesesuaian biaya dalam pembuatan KTP dengan yang sudah ditetapkan dalam Peraturan Daerah (Perda).

Di Indonesia, hamper semua daerah mengalami permasalahan yang sama. Belum hilangnya istilah birokrasi yang berbelit-belit, biaya yang mahal, akses yang sulit dan waktu yang lama dalam pengurusan KTP membuat masyarakat menjadi malas dalam pengurusan KTP. Salah satunya di Kecamatan Lubuk Baja Kota Batam yang merupakan salah satu kecamatan dari 12 (dua belas) kecamatan yang ada di Kota Batam. Keberadaan wilayah kerja Kecamatan Lubuk Baja tepat berada di jantung perdagangan dan jasa Kota Batam dan merupakan salah satu kecamatan yang memiliki penduduk yang cukup besar yang terdiri dari berbagai etnis yang ada di Indonesia.

Dengan begitu besarnya penduduk yang ada pada Kecamatan Lubuk Baja dengan sendirinya tentu akan menuntut adanya pelayanan publik yang besar pula kepada masyarakat. Selain sebagai fungsi perangkat daerah kecamatan juga merupakan barisan terdepan yang langsung berhadapan dengan masyarakat. Salah satu pelayanan yang diberikan kepada masyarakat di Kantor Kecamatan adalah pelayanan kartu tanda penduduk (KTP).

Berdasarkan Peraturan Daerah Kota Batam Nomor 8 Tahun 2009 tentang penyelenggaraan administrasi kependudukan di Kota Batam bahwa Dinas Kependudukan dan Pencatatan Sipil merupakan sebagai leading sector yang menangani terkait dengan pendaftaran penduduk dan pencatatan sipil yang ada di Kota Batam. Salah satu jenis pelayanan dalam pendaftaran penduduk dan pencatatan sipil adalah pembuatan kartu tanda penduduk (KTP). Walaupun didalam pembuatan Kartu Tanda Penduduk leading sector nya adalah Dinas Kependudukan dan Pencatatan Sipil, akan tetapi didalam proses pemberkasannya sangat bergantung kepada pelayanan yang ada di kantor kecamatan dan Kelurahan.

Akan tetapi didalam pelaksanaannya sering timbul permasalahan-permasalahan yang dihadapi didalam memberikan pelayanan kepada masyarakat, dan banyak menimbulkan kritik dan persepsi negatif dari masyarakat dikarenakan belum maksimalnya pelayanan yang diberikan. Dikarenakan fenomena-fenomena tersebut penulis sangat tertarik dengan 
permasalahan tersebut dan mencoba melakukan penelitian mengenai peranan aparatur pemerintah dalam pelayanan pengurusan kartu tanda penduduk di Kecamatan Lubuk Baja

\section{METODOLOGI PENELITIAN}

Penelitian ini bersifat deskriptif yakni prosedur pemecahan masalah yang diselidiki dengan melukiskan atau menggambarkan keadaan subyek / obyek penelitian saat ini berdasarkan fakta-fakta sebagaimana adanya. Sedangkan pendekatan penelitian yang akan dipakai guna memperoleh ketepatan dengan metode deskriptif ini adalah secara kualitatif. Sumber data yang digali peneliti sesuai dengan pokok masalah diantara nya para aparat birokrasi, masyarakat dan beberapa dokumen. Penelitian kualitatif tidak bermaksud untuk menggambarkan karakterisktik populasi atau menarik generalisasi kesimpulan yang berlaku bagi populasi (seperti penelitian kuantitatif) melainkan lebih terfokus pada representasi terhadap fenomena sosial. Data dan informasi pada penelitian kualitatif harus ditelusuri seluas-luasnya (dan sedalam mungkin) sesuai dengan variasi yang ada. Hanya dengan cara demikian, peneliti mampu mendeskripsikan fenomena yang diteliti secara utuh.

Berkenaan dengan tujuan penelitian kualitatif diatas, maka pada prosedur sampling, yang terpenting adalah bagaimana penentuan informan (key forman) atau situasi sosial tertentu yang sarat informasi sesuai dengan syarat penelitian. Sehingga untuk memilih sampel (sampling) yang digunakan bukanlah sampel statistik atau probability sampling seperti yang dilakukan pada penelitian kuantitatif. Namun lebih bersifat selektif, dimana peneliti menggunakan berbagai pertimbangan berdasarkan konsep/teoritis yang dipergunakan, keingintahuan pribadi dan karakteristik pribadi, sehingga diharapkan mampu menangkap berbagai informasi kualitatif dengan deskripsi yang penuh arti, yang lebih berharga dari sekedar pertanyaan jumlah atau frekuensi dalam bentuk angka.

\section{PEMBAHASAN}

Dalam pelaksanaan pelayanan tidak hanya berhubungan dengan sarana dan prasarana yang memadai, melainkan juga yang lebih penting yaitu unsur manusia yang memberikan pelayanan. Tuntutan terhadap pelayanan yang baik adalah bagaimana bentuk dari pelayanan yang diberikan serta kontribusinya bagi organisasi yang bersangkutan. Dengan pelayanan yang baik, yang telah diberikan kepada masyarakat dan yang sudah sesuai dengan prosedur dan aturan yang telah ditetapkan. Maka dengan harapan masyarakat sebagai penerima jasa pelayanan tersebut akan merasa puas, dari pelayanan yang diberikan. Hal ini diharapkan akan 
semakin mampu meningkatkan kepercayaan masyarakat. Dalam era otonomi daerah saat sekarang ini, dalam memberikan pelayanan di tuntut untuk mampu memberikan suatu bentuk pelayanan publik yang baik, cepat, tepat dan berkualitas serta maksimal kepada masyarakat. Untuk melihat bagaimana pelaksanaan pelayanan pengurusan Kartu Tanda Penduduk (KTP) di Kecamatan Lubuk Baja Pemerintah Kota Batam dapat dilihat dari beberapa dimensi yang dikembangkan menjadi suatu pedoman wawancara guna menganalisa bagaimana pelaksanaan pelayanan tersebut dapat berjalan, hal ini dapat dilihat dari ketentuan yang sesuai dengan Peraturan Menteri Pendayagunaan Aparatur Negara Dan Reformasi Birokrasi Nomor 36 Tahun 2012 Tentang Petunjuk Teknis Penyusunan, Penetapan, dan Penerapan Standar Pelayanan. Dalam menyusun, menetapkan dan menerapkan standar pelayanan dilakukan dengan memperhatikan prinsip:

\section{SEDERHANA}

Standar Pelayanan yang mudah dimengerti, mudah diikuti, mudah dilaksanakan, mudah diukur, dengan prosedur yang jelas dan biaya terjangkau bagi masyarakat maupun Penyelenggara. Pelayanan dalam pengurusan KTP yang diberikan aparatur pemerintah di Kecamatan Lubuk Baja Kota Batam kepada masyarakat yang dapat dilihat dari sisi kesederhanaan pengurusan yang meliputi prosedur pelayanan sehingga mudah dimengerti dan dapat diikuti prosedur yang jelas dan biaya yang terjangkau. Berdasarkan hasil penelitian yang dilakukan dapat dikatakan bahwa untuk prosedur yang ada sudah sesuai dengan aturan dan kentuan yang berlaku sebagai mana yang dikatakan dari enam informan "untuk saat ini standar pelayanan yang diberikan dari kesederhanaan prosedur dan ketentuan sudah baik dan ini diupayakan dapat dipertahankan dan ditingkatkan dimasa mendatang", dimana dalam setiap pengurusan selalu memiliki peraturan yang sama. Misalnya dalam pembuatan KTP sudah ada persyaratan, prosedur dan ketentuannya sehingga jika masyarakat ingin mendapatkan pelayanan yang diinginkan hendaknya masyarakat juga harus mengikuti persyaratan dan mengikuti prosedur dan kentuan yang ada dan secara umum dapat disimpulkan kederhanaan pada pelayanan berada pada kategori baik.

\section{KONSISTENSI}

Dalam penyusunan dan penerapan standar pelayanan harus memperhatikan ketetapan dalam mentaati waktu, prosedur, persyaratan, dan penetapan biaya pelayanan yang terjangkau. Pelayanan yang diberikan pegawai di Kecamatan Lubuk Baja Pemerintah Kota Batam yang tidak melakukan diskriminasi kepada masyarakat dilihat dari aspek apapun 
khususnya ras, agama, golongan, suku status sosial dan lainnya dengan memperhatikan ketetapan dalam waktu, prosedur. Dari hasil penelitian bahwa untuk kesamaan hak sudah berjalan dengan baik dan ini sebagaimana yang dikatakan ketujuh orang informan "untuk kesamaan hak pelayanan yang diberikan sudah baik tidak adanya perbedaan satu dengan lainnya sesuai dengan haknya sebagai warga penduduk". semua masyarakat dengan berbagai macam pengurusan sudah dilayani dengan baik. tanpa melihat status sosial, pekerjaan. Sedapat mungkin pihak Kecamatan Lubuk Baja Pemerintah Kota Batam akan membantu. Hanya saja untuk sistem antrian yang kembali harus diperhatikan terkait waktu dan prosedur. Harus ada pembenahan dan solusi dari hal tersebut agar masyarakat merasa nyaman saat mengantri tanpa merasa pegawai tidak konsisten dalam memberi pelayanan dan pilih kasih.

\section{PARTISIPATIF}

Penyusunan Standar pelayanan dengan melibatkan masyarakat dan pihak terkait untuk membahas bersama dan mendapatkan keselarasan atas dasar komitmen atau hasil kesepakatan. Partisipatif adalah pelayanan yang mendorong peran serta masyarakat dalam penyelenggaraan pelayanan publik dengan memperhatikan aspirasi masyarakat, kebutuhan serta harapan masyarakat. Dari hasil penelitian maka dapat diambil kesimpulan bahwa untuk pelayanan partisipatif, harus lebih ditingkatkan walau sekarang sudah berjalan baik, sejalan dengan pemenuhan kebutuhan masyarakat sebagaimana yang dikatakan salah satu dari sembilan informan yang berpendapat baik mengatakan "standar pelayanan yang melibatkan partisipasi masyarakat dan pihak terkait akan senantia terus ditingkatkan meskipun sekarang sudah baik". Salah satu tugas pokok yang harus dilakukan oleh birokrasi, yakni menyediakan dan menyelenggarakan pelayanan bagi masyarakat. Sebagai warga negara, setiap individu mempunyai hak yang sama untuk menerima pelayanan dari birokrasi dan pemenuhan terhadap kebutuhannya.

\section{AKUNTABEL}

Hal-hal yang diatur dalam standar pelayanan harus dapat dilaksanakan dan dipertanggungjawabkan secara konsisten kepada pihak yang berkepentingan. Pelayanan dapat dipertanggungjawabkan sesuai dengan ketentuan peraturan perundang-undangan. Akuntabilitas dalam pelayanan publik di Kecamatan Lubuk Baja Kota Batam dilihat dari persyaratan teknis dan administratif harus jelas dan dapat dipertanggungjawabkan dari segi kualitas dan keabsahan pelayanan. Selain dari itu prosedur dan mekanisme kerja harus sederhana dan dilaksanakan sesuai dengan ketentuan yang telah ditetapkan. Dari hasil 
penelitian bahwa untuk akuntabilitas di Kecamatan Lubuk Baja Kota Batam mengenai kepastian waktu dan biaya haruslah menjadi perhatian walau sudah berjalan baik sebagaimana yang dikatakan salah satu dari informan staff kecamatan "untuk kepastian waktu memang udah ada ketentuannya namun kadang kala dapat lebih cepat dari waktu yang ditetapkan dan jarang sekali terjadi kelambatan untuk itu hal yang demikian masih perlu mendapatkan perhatian". Seperti membuat papan persyaratan, alur prosedur yang berisi biaya dan waktu penyelesaian setiap pengurusan. Jika terjadi keterlambatan terhadap penyelesaian maka haruslah diinformasikan terlebih dahulu. Begitu juga dengan biaya jika ada perubahan dengan biaya yang harus dikeluarkan masyarakat maka harus terlebih dahulu dijelaskan kepada masyarakat sebagai bentuk akuntabilitas dalam meningkatkan pelayanan yang berkualitas di Kecamatan Lubuk Baja Kota Batam.

\section{BERKESINAMBUNGAN}

Standar pelayanan harus dapat berlaku sesuai perkembangan kebijakan dan kebutuhan peningkatan kualitas pelayanan. Pelayanan yang diberikan sesuai kondisi dan kemampuan pegawai di Kecamatan Lubuk Baja Pemerintah Kota Batam dan masyarakat dengan tetap berpegang pada efisiensi dan efektivitas. Kemampuan pemerintah dalam mengahadapi kendala-kendala yang terjadi dalam pelayanan yang diberikan kepada masyarakat. Sehubungan dengan pelaksanaan pelayanan dari Kecamatan Lubuk Baja Pemerintah Kota Batam maka dapat diambil suatu kesimpulan bahwa untuk tindakan dalam menghadapi keluhan masyarakat sudah baik sebagaimana juga yang dikatakan informan dari penduduk setempat "untuk saat ini usaha dari pihak kecamatan dalam menghadapi kendala pelayanan yang terjadi yang diberikan sudah baik dengan upaya dan usaha yang dilakukan". Ini dapat dilihat jika masyarakat mengeluhkan sesuatu misalnya persyaratan yang berbelit belit, atau tidak pahamnya masyarakat terhadap prosedur yang ada dan lain sebagainya selalu langsung ditanggapi dengan baik. Jika ada masalah yang tidak dapat teratasi biasanya pegawa $i$ akan mencatatnya dan mengadukan ke atasan yang lebih tinggi dan berwenang untuk menyelesaikannya.

\section{TRANSPARANSI.}

Pelayanan yang bersifat terbuka harus dapat dengan mudah diakses dan diketahui oleh seluruh masyarakat. Pelayanan dalam pengurusan KTP yang diberikan aparatur pemerintah di Kecamatan Lubuk Baja Kota Batam kepada masyarakat yang dapat dilihat dari sisi kesederhanaan alur pelayanan pengurusan yang meliputi prosedur pelayanan sehingga mudah 
dimengerti. Dari hasil penelitian dapat diketahui bahwa untuk prosedur dan persyaratan yang ada sudah sesuai dengan aturan dan kentuan yang berlaku, dalam setiap pengurusan selalu memiliki peraturan yang sama dapat dikatakan dalam hal ini transparansi sangat baik sebagaimana juga yang dikatakan salah satu dari informan key "untuk pengurusan peraturan tetap sama prosedur dan persyaratan sudah sangat baik". Misalnya dalam pembuatan KTP sudah ada persyaratan dan prosedur kerjanya sehingga jika masyarakat ingin mendapatkan pelayanan yang diinginkan hendaknya masyarakat juga harus mengikuti persyaratan yang ada.

\section{KEADILAN}

Standar pelayanan harus menjamin bahwa pelayanan yang diberikan dapat menjangkau semua masyarakat yang berbeda status ekonomi, jarak lokasi geografis, dan perbedaan kapabilitas fisik dan mental. Yaitu pelayanan yang mempertimbangkan dari aspek keadilan antara pemberi layanan dan penerima layanan publik. Dari hasil penelitian dapat ditarik kesimpulan hak dan kewajiban pengguna layanan masih perlu mendapat perbaikan walaupun sebgian sudah berjalan baik sejalan dengan yang dikatakan salah satu dari informan "Sebagian besar dari hak dan kewajiban penduduk sebagai pengguna layanan sudah berjalan baik" dan masyarakat wajib mengetahui tentang informasi baik dari segi biaya dan waktu. dan Dinas Kependudukan wajib memberikan informasi secara terbuka kepada masyarakat.

\section{KESIMPULAN}

Kesimpulan dari penelitian ini, yaitu peran aparatur pemerintah dalam Pelaksanaan Pelayanan pengurusan Kartu Tanda Penduduk (KTP) di Kecamatan Lubuk Baja Pemerintah Kota Batam sudah baik namun masih belum seperti dengan yang diharapkan, ada beberapa hal yang harus diperhatikan. Dilihat dari dimensi standar pelayanan yang diantaranya adalah :

a. Sederhana

Kesederhanan prosedur pelayanan tidak berbelit-belit dan mudah dilaksanakann hanya saja karena tidak dipublikasikan maka masyarakat mengalami kesulitan dalam melihat prosedur, tata cara, dalam pelaksanaan pelayanan tersebut.

b. Konsistensi

Konsistensi dalam memberikan pelayanan dalam penerapan standar pelayanan harus memperhatikan ketetapan dalam mentaati waktu, prosedur, persyaratan, dan penetapan biaya pelayanan yang terjangkau. Pelayanan yang diberikan pegawai di Kecamatan 
Lubuk Baja Pemerintah Kota Batam saat ini dilakukan dengan memperhatikan ketetapan dalam waktu, prosedur dan biaya sudah berjalan dengan baik. Hanya harus ada pembenahan dan solusi dari pegawai di Kecaamatan Lubuk Baja Pemerintah Kota Batam agar masyarakat merasa nyaman saat mengantri tanpa merasa pegawai tidak konsisten dalam memberi pelayanan dan pilih kasih.

c. Partisipatif

Salah satu yang harus memang seharusnya dilakukan oleh birokrasi, yakni menyediakan dan menyelenggarakan pelayanan bagi masyarakat. Sebagai warga negara, setiap individu mempunyai hak yang sama untuk menerima pelayanan dari birokrasi dan pemenuhan terhadap kebutuhannya.

d. Akuntabel

Akuntabilitas harus menjadi perhatian bagi pihak Kecamatan Lubuk Baja Pemerintah Kota Batam guna meningkatkan pelayanan kepada masyarakat secara Persyarakatan teknis dan administrasi harus jelas dan ini dapat dilihat dari waktu dan biaya dalam pelaksanaan pelayanan harus diinformasikan pegawai kepada masyarakat sesuai dengan peraturan yang berlaku tetapi pada kenyataannya masyarakat sering tidak mendapatkan kepastian waktu serta kepastian biaya yang dituangkan dalam rincian-rincian dan diberitahukan secara jelas oleh para pegawai.

e. Berkesinambungan

Pelayanan yang berkesinambungan peraturan-peraturan yang berlaku di Kecamatan Lubuk Baja Pemerintah Kota Batam sesuai dengan kondisi, memperoleh perlindungan hukum dalam melaksanakan tugas dan fungsinya sebagai di Kecamatan Lubuk Baja Pemerintah Kota Batam sudah berjalan dengan cukup baik, begitu juga dalam memberikan informasi pelayanan kepada pengguna layanan, tetapi melayani sesuai standar menjadi salah satu poin untuk diperbaiki karena pegawai bekerja terkadang tidak sesuai dengan standar yang ada seperti tidak memakai tanda pengenal, tidak memakai baju seragam, menegur pengguna layanan yang tidak mengikuti ketentuan pelayanan sudah dilaksanakan dengan baik oleh para pegawai.

f. Transparansi

Keterbukaan dalam memberikan pelayanan sudah cukup baik Kemudahan tahapan pelayanan yang dijelaskan melalui bagian-bagian melalui papan petunjuk, proses dan tata cara segala pengurusan di Kecamatan Lubuh Baja Pemerintah Kota Batam papan petunjuk yang ada sudah cuku baik dan mudah dipahami oleh masyarakat. 
g. Keadilan

Keadilan dalam pelayanan sudah berjalan dengan baik para pegawai melayani masyarakat tanpa pilih kasih hanya saja dalam antrian perlu dibenahi karena masalah yang sering timbul adalah pegawai tidak mengetahui siapa yang akan dilayani duluan karena tidak ada sistem antrian sehingga masyarakat menilai bahwa pegawai pilih kasih dan tidak memperhatikan siapa yang datang lebih dulu.

\section{SARAN}

Saran dari penelitian ini yaitu pemerintah sebagai pemberi pelayanan publik harus melakukan perbaikan-perbaikan dalam pemberian pelayanan publik terutama terhadap peningkatan kualitas sumber daya manusia atau aparatur pemerintahnya agar tercipta pelayanan yang maksimal.

\section{DAFTAR PUSTAKA}

Anonim. 1993, Kebijaksanaan Nasional Penyelenggaraan Penyuluhan Pertanian, Deptan RI, Jakarta.

Gaspersz, V., 1994, Manajemen Kualitas, Gramedia, Jakarta.

Islamy, M. Irfan, 1992, Prinsip-prinsip Perumusan Kebijaksanaan Negara, Jakarta, Bumi Aksara.

Moenir, H.A.S., 1992, Manajemen Pelayanan Umum di Indonesia, Bumi Aksara, Jakarta.

Moerdiono, 1992, Birokrasi dan Administrasi Pembangunan : Beberapa Pemikiran Pemecahan, Sinar Grafika, Jakarta.

Moleong, Lexy J., 1995, Metodologi Penelitian Kualitatif, Remaja Karya, Bandung.

Osborne, David, dan Ted Gaebler, 1992, Reinventing Government : How the Entrepreneurial Spirit is Transforming the Public Sector, Addison-Wesley.

Robbins, S.P., 1995, Managing Organizational Conflict : A Non-Traditional Approach, Englewood Cliffs, NJ:Prentice Hall.

Soetopo, 1999, Pelayanan Prima, LAN RI, Jakarta.

Sugiyono, 2014, Metode Penelitian Kuantitatif, Kualitatif, Dan Kombinasi (Mixed Methods), Alfabeta, Bandung.

Tjiptono, Fandy, 1995, Strategi Pemasaran, Andi Offset, Jogjakarta. 
Widodo, Joko, 2001, Good Governance : Telaah dari Dimensi Akuntabilitas dan Kontrol Birokrasi Pada Era Desentralisasi dan Otonomi Daerah, Insan Cendekia, Surabaya.

Wasistiono, Sadu, 2002, Menata Ulang Lembaga Pemerintahan Kecamatan, Citra Pindo, Bandung.

W.J.S. Poerwadarminta. 2005, Kamus Besar Bahasa Indonesia. Jakarta, Balai Pustaka.

Zeithaml, Valarie A., (et.al), 1990, Delivering Quality Services : Balancing Customer Perceptions and Expectations, The Free Press, A Division of Macmillan Inc., New York.

Undang-undang Negara Republik Indonesia Nomor 23 Tahun 2006 tentang Administrasi Kependudukan.

Peraturan Daerah Kota Batam Nomor 8 Tahun 2009 tentang Penyelenggaraan Admistrasi Kependudukan di Kota Batam 